\title{
Sociology as a Science
}

\author{
Sherzod Salimov ${ }^{1 *}$ and Khuchkarov Vakhob Khashimovich ${ }^{2}$ \\ ${ }^{1}$ Head department of the Scientific and Enlightenment Complex named after the First President the Republic of Uzbekistan Islam Karimov, \\ Tashkent, Uzbekistan
}

${ }^{2}$ Scientific researcher, Tashkent, Uzbekistan

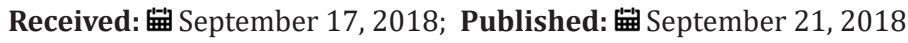

*Corresponding author: Sherzod Salimov, Scientific researcher, Tashkent, Uzbekistan

\begin{abstract}
In the time of Enlightenment, the idea of science was to promote the Good society. There was yet not perceived to be a contradiction in science between at the same time being objective and progressive. A century ago, though philosophers and scientist discovered the problem language poses for science: there is a difference between the world and the words. The response from the scientist was paradoxically to defend objectivity. Thus, when sociology was established as a science around the year 1900 it became inherently contradictory, i.e., at the same time being objective and geared at social reforms. (cf. Lindgren 2011) In this article is attempted an outline of a possible solution to this problem in terms of hermeneutics and phenomenology. The conclusion is: by taking understanding as the point of departure sociology can be progressive: promoting the good society and still be a science.
\end{abstract}

Keywords: Sociology; Science; Society; Post-Modernism; Positivism; Post-Positivism; Phenomena; Meaning; Language

\section{The Good Society}

The aim of science is to promote the Good society. This is - since the time of Enlightenment - the meaning of science Kant [1]. At that time science was understood as inherently progressive: contributing to a better, good society Hampson. This progressiveness characterized also sociology a hundred years later when it was established as a science of the society Durkheim [2]. Though now objectivity also was stressed, causing a contradiction between what is - i.e., the objectivity of science - and what ought to be - politics, i.e., the concerns for ideologues. Weber [3]. Thus, it seemed impossible to promote the Good society in the name of science.

\section{Understanding and Thinking}

Sociology is the science of society, but what is society? Is it an object Durkheim [4] A very old notion of society is that it is togetherness Gadamer? How can we come to an answer to the question of what the society is? First, we must make society into a problem. A precondition for answering the question is that society can be something different from the given society that we live in and how this is conceived Kant [1].
The idea that things can be different makes critical thinking possible Kant [1,5]. Critical thinking by necessity starts with the notion that there is a difference between that what "is given" and that what can be. In general, we just repeat that which we have been taught but in order to think - e.g., about society - we must discover the difference between that which "is": the "given" and that which "can be". One may say that thinking starts with this difference and is spontaneously, by nature is critical ${ }^{1}$.

\section{Is or Ought}

One might believe that this is obvious to everyone interested in science and social science but on the contrary: it is not so. In "society" and science, society is presented up-side down Marx [6]. In science a since then long-lasting distinction was made at the beginning of the $20^{\text {th }}$ century between that which "is" and that which "ought" to be. Max Weber, an early German sociologist said that science deals with "is" while "ought" to belong to ideology and politics. Weber [7]. For our purpose, elaborating on the meaning of sociology as a science of society it is useful to refer to Wilhelm Dilthey [8], a German contemporary of Weber who made a distinction between "science" and "the human science". He declared "nature we explain,

${ }^{1}$ That is why "critical theory" by definition is anti-positivism. Cf. Krogh 1984. 
culture we understand" Eliasson. In this time, at the end of the $19^{\text {th }}$ century the idea was emerging that maybe there is a difference between social - or Human - science and science, i.e., science about nature? Those propagating "positivism" soon claimed that there is but only one kind of science and knowledge is empirically tested propositions about the world Carnap [9], Vienna circle [10]. Though there since then have been many different opinions about science - Mach, Russell, Wittgenstein, to name only those following the "positivist" track Johansson and Liedman [11] - the distinction between "is" and "ought" to still hold today: it is not challenged. No matter if "the object" of science is nature or culture, science still is about "is" and "is" is "empirical". Weber supported the "positivists" by claiming that social science is about "is". To Weber society was ridden by value-conflicts but this science could not do anything about. Thus, a critique of society - an imagining that the given society can be different; can be changed - to him is not-science but instead something political, ideological. That which distinguishes science is its "value-freedom" Weber [7].

\section{What is is?}

There is a problem though with this little word "is", something which other German speaking philosophers and scientists had discovered at the same time - Mach, Herz and most explicitly Gottlob Frege - and analytical philosophers have struggled with this little word ever since. The problem they - only "sub consciously" Freud [12] though, since they never gave up the opposite idea - discovered is that there is a difference between the world and the words. Since then first the logical-positivists and then the analytical philosophers - e.g.., Russell, Wittgenstein ${ }^{2}$ - and later the post-modernists - e.g., Rohrty, Derrida - have struggled with the troublesome relationship between the words: language and the "empirical" world. The first mentioned - "analytical positivists" is a good name we can give them all since they all - have in wane been trying to save "science" by establishing a connection between the words and the world. The outcome of post-modernism is also positivism: as "post-positivism" - in practice - though they have resigned to the world of language Derrida. Still, these early German philosophers discovered something fundamental for our understanding of the every-day world: that words and phenomena are different things and that there is also "meaning". Then, when we talk use language there are three things present; the language/ words, the things/phenomena and the meaning. Communication: talking takes place within language and language is self-referring: tautological ${ }^{3}$. In themselves, words have no meaning they are empty; a "tree" is a "tree" etc. The things they sometimes refer to ${ }^{4}$ have different words in different languages and the things thus have nothing to do with the words. There is also "meaning", something we want to "understand", communicate etc. The meaning - and the phenomena/things - is beyond, before etc the words: language ${ }^{5}$. Thus "is" is only a word and that is why we must look somewhere else than in this word for the meaning of society.

\section{Phenomena and Meaning}

Then the "understanding" of Dilthey is still an alternative to "empirical science/positivism". Following Dilthey human science is about "understanding culture" i.e., "society". In order to understand society, we can also use phenomenology. At the time of Dilthey and Weber, Edmund Husserl was developing his new science of "phenomenology". Husserl said that we have to go to "the things themselves". In order to do so we must do "a phenomenological reduction", that is we must free ourselves of social interpretations. Then the things appear "in themselves": as they really are: in their essence/meaning. In the sensuous experience: in "looking" one can look beyond the phenomena and experience the real thing, as a feeling of truth: understanding Husserl [13]. Thus - by combining hermeneutics and phenomenology - especially in the way Heidegger [14] and Gadamer later did - we can say that knowledge, as truth is a relationship between the thing/phenomenon and its meaning. Understanding thus is a sensuous experience Husserl [13] where we use our bodies doing the thinking - i.e., in order to go beyond, before etc. language: Understanding - and not understanding - is sensuously experiencing the relationship between the phenomena/ thing and their meaning.

\section{The meaning of society}

Thus, in order to be scient fique, i.e., to understand the society we must overcome the world of words: language. Then, in order to promote the Good society, we can use ourselves; our feelings of society in changing society. Lindgren ${ }^{6}$. We also need to play with the words: language in order to overcome the given society: to think differently i.e., critically Lindgren [14-23].

\section{Refrences}

1. Immanuel Kant (1784) Idé till en historia i världsmedborgerlig avsiktSvar på frågan: Vad är upplysning? (2010-1124).

2. Emile Durkheim (1897) Självmordet. Argos. Lund 1968.

3. Max Weber (1912) Samhällsvetenskapens objektivitet in Tre klassiska texter. Bokförlaget Korpen. Göteborg 1991.

${ }^{2}$ Cf. Jalink and Toulmin, Kraft 1969.

${ }^{3}$ Especially the late Wittgenstein made this clear, as "language-games" in his philosophical investigations, 1953 but it is tacitly

acknowledged in any attempt to construct, create a language, cf. Kraft 1969.

${ }^{4}$ Frege used the word "bedeutung" for this relationship and the analytical philosophers have stuck to this "meaning of meaning", cf., the late Wittgenstein.

${ }^{5}$ This is part of what I have tried to develop n my books from 2005, 2006, 2007, 2008 and 2009.

${ }^{6} \mathrm{Critical}$ thinking then includes; language, phenomena/things/feelings and meaning. 
4. Emile Durkhem (1895) Sociologins metodregler. Korpen förlag. Göteborg 1978.

5. Immanuel Kant (1781) Kritik av det rena förnuftet. Thales. Stockholm 2004.

6. Karl Marx (1857) Grundrisse. Foundations of the Critiquee of Political Economy (Rough Draft). Penguin Books. UK 1977.

7. Max Weber (1912) Vetenskap som yrke in Tre klassiska texter. Bokförlaget Korpen. Göteborg 1991.

8. Wilhelm Dilthey (1883) Introduction to the Human Sciences. Selected Works, Princeton University Press. USA 19891.

9. Rudoolf Carnap (1928) Der logische Aufbau der Welt. Berlin: Weltkreis.

10. Vienna circle (1929) The scientifique conception of the world. Vienna circle (2011-10-18).

11. Ingvar Johansson and Sven-Eric Liedman (1993)) Positivism and marxism. Daidalos. Uddevalla 1997.

12. Sigmund Freud (1917) 1. Introductory Lectures on Psychoanalysis. Penguin Books. England 1991.

13. Edmund Husserl (1900) Logiska undersökningar, del 2. Thales. Stockholm 2000.
14. Martin Heidegger (1949) Brev om humanismen. Bokförlaget Thales. Norge 1996.

15. Martin Heidegger (1993) Varat och tiden. Daidalos. Uddevalla.

16. Emile Durkheim (1893) The Social Division of Labor in Society. The Free Press. USA 1964.

17. Edmund Husserl (1913) Fenomenologins idé. Daidalos: Uddevalla. 1995.

18. Allan Janik and Stephen Toulmin (1973) Wittgenstein's Vienna. Elephant Paperbacks: Chicago.

19. Immanuel Kant (1790) Kritik av omdömeskraften. Thales. Stockholm 2003.

20.Victor Kraft (1969) The Vienna circle. New York: Greenwood Press, 1969.

21. Thomas Krogh (1984) Frankfurtskolan: en introduction. Daidalos. Göteborg 1993.

22. Antoni Lindgren (2011) Science and Sociology in Asian Social Science, Vol. 7, No. 6 June 2011.

23. Ludwig Wittgenstein Filosofiska undersökningar (1953). Stockholm: Bonniers, 1978.

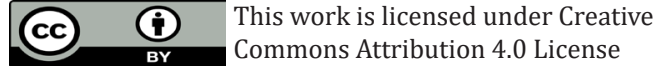

To Submit Your Article Click Here: $\quad$ Submit Article

DOI: $10.32474 /$ LOJMS.2018.01.000120

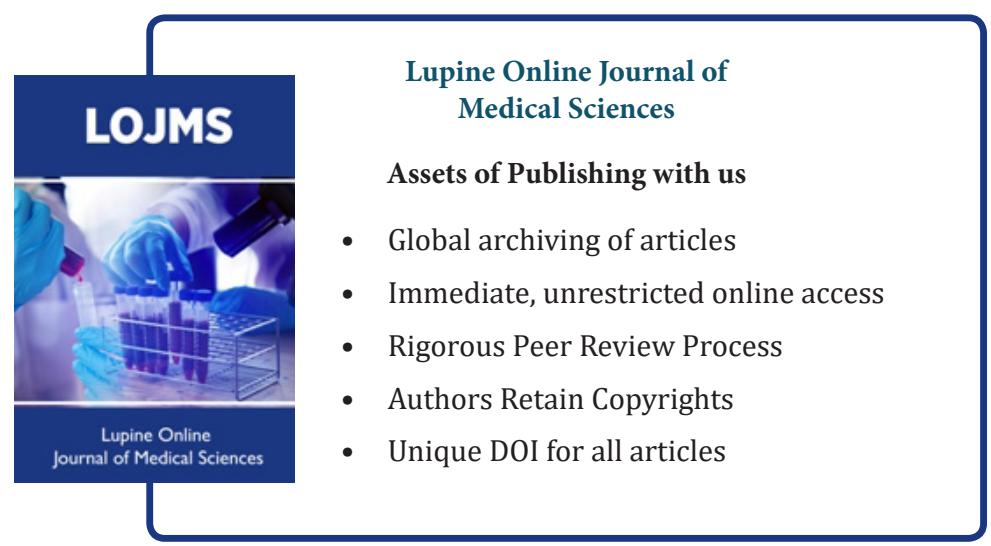

